\title{
石英の変形 - 再結晶と水
}

\author{
相 川信 之*
}

Effect of Water on the Deformation and Recrystallization of Quartz

Nobuyuki AIKAWA*

\begin{abstract}
Quartz grains within granitic mylonite from the Median Tectonic Line (MTL) contain significant amounts of water (from 2500 to 10500 ppm) with IR signatures. Most of this water is freezable, and may differ from those within natural vug-grown quartz and synthetic single crystals. Quartz grains in strongly sheared mylonites may contain large number of fine (less than $500 \mathrm{~nm}$ in diameter) inclusions along dislocations which bear a resemblance to bubbles developped within heat-treated wet synthetic quartz. This water within extremely fine inclusions may be effective for the hydrolytic weakening of rocks within the earth's crust.
\end{abstract}

\section{1. はじめに}

“水”の存在の重要性は鉱物の反応性や拡散, 力学的 性質を大きく変化させることにある. 例えば，“水”の 存在下では珪酸塩鉱物や岩石の強度が急激に低下する事 が実験的に示された（例えば，1，2）。この現象は “hydrolytic weakening”とか“water weakening”と呼ば れている. また, 石英中の酸素の拡散係数3)4) も水の存 在下では無水時に比べて格段に大きくなることや，無水 の状態では考えられないほどイオン交換や相変化などの 化学反応が進行すること占が知られている. 自然の条件 下では, 岩石・鉱物中に多少の“水”が常に存在するし, 本来無水鉱物である石英, カンラン石, 輝石などでも微 量であるが“水”が存在すること7など考えれば，造構 作用時の岩石・鉱物の変形 - 流動 - 再結晶7)の過程で “水”が重要な役割を果たしたと考えられる. 従って, 変形・流動・再結晶とそれに伴う組織変化の形成機構を 理解する上で, “水” の役割を考えることは重要である. これは微量の “水”が鉱物中に入り込み, $\mathrm{Si}-\mathrm{O}$ 結合の 切断を容易にすること帛年よると考えられているが，実 際に水がどのような化学種として，との程度の速度で鉱 物中に入り込むのか, さらにどの程度溶け込むのかと言 ったことに関してはよく解っていないのが現状である.

1993年 8 月 31 日受理

* 大阪市立大学 理学部 地球学教室

Department of Geosciences, Faculty of Science, Osaka City University, 3-3-138, Sugimoto, Sumiyoshi-Ku, Osaka 558
ところで，これまでの石英中の “水”に関連する多く の実験的研究(例えば, $10,11,12,13$ )が合成石英や天然 の大型の単結晶などに限定されていた．自然の岩石を構 成する細粒の石英にこれらと同様の“水”が存在するの か, あるいは異なる “水”が存在するのか検討する必要 がある. 即ち, 自然の岩石を構成する鉱物としての石英 中の “水”がどの様な化学種で, どの程度存在するかを 明らかにすることは, 自然での多種多様な石英の組織形 成過程での “水” の役割を理解する上で重要であろう.

この報告では，はじめに石英中の “水” と石英の変形 について簡単に解説し, 自然の種々の岩石中の石英粒中 の “水” の化学種, 分布, 存在量を検討した例として, 中央構造線近傍の花崗岩と花崗岩質マイロナイトを構成 する石英中の “水”について検討した結果を報告する.

\section{2. 石英中の “水”}

石英に見られる “水” の化学種は大きく 4 種に分類さ れている.しかし，この“水”が転位の運動や拡散にど のような機構で関与しているかほとんど解っていない. なお，石英中の “水”については, Paterson (1989) ${ }^{14)}$ にる総合報告に詳しいので参照されたい。

イ), ガーネットに知られている $(4 \mathrm{H})_{\mathrm{Si}}$ で示される置換 型の “水” の欠陷 ${ }^{15)}$ と $\left(\mathrm{H}_{2} \mathrm{O}\right)_{\mathrm{i}}$ あるいは $(2 \mathrm{OH})_{\mathrm{o}}$ で示さ れる格子間型の “水” の久陷 ${ }^{16)}$. 石英構造中への溶解度 はそれほど大きくないと考えられており，(4H) $)_{\mathrm{Si}}$ で数 ～数十 $\mathrm{ppm}$ 以下で $(2 \mathrm{OH})_{\mathrm{O}}$ では $(4 \mathrm{H})_{\mathrm{Si}} よ り 1$ 析小さい と考えられている17)。これは赤外吸収法での検出限界以 
下かもしれない，拡散速度についてははっきりしない が, 置換型の欠陥は遅く, 格子間型の欠陷も転位や界面 に沿った移動を考えない限り遅いと考えられるが，分子 軌道法による計算から速いと予想されてもいる18)。この 種の “水”の欠楩が転位すべりを促進させるモデル (hydrolytic weakening $の$ 微視的機構) が提案されてい Ђ $^{19) 20)}$.

ロ), $\mathrm{Al}\left(\mathrm{Fe}^{+3}\right)$ が $\mathrm{Si}$ を置き換えることによって生じた電 荷の不足をバランスさせるために, 構造中に $\mathrm{H}^{+}(\mathrm{Li}$, $\mathrm{Na}$ など)をともなう形の欠陥.この種の欠陥の溶解度 は不純物としての $\mathrm{Al}$ の量によって決まり最大 $100 \mathrm{ppm}$ ( $\mathrm{Li}, \mathrm{Na}$ を含めて) 程度までと考えられる.アルカリと $\mathrm{H}$ の交換反応速度は速い10)とされているが，欠陥自身 の拡散能は低いと考えられており，Hydrolytic weakeningに有効ではないかもしれない。

八), 化学吸着された水; 不連続面(粒界, 流体包有物の 表面など), クラックなど各種界面に存在する水(転位芯 にもこの種の化学種が存在可能であるが, 既に 1 のタイ プとして述べた)。この種の水の変形に対する効果は粒 子サイズが $\mathrm{mm}$ 規模であれば無視できると思われるが， $\mu \mathrm{m}$ サイズの微小な多結晶体では重要になると考えられ $3^{14)}$.

二), 分子水の集合体; 集合した水分子の形で石英中に 存在する.この水の集合体は光学頭微鏡下で観察可能な 流体包有物から電子顕微鏡でも識別困難な小さなサイズ のものまで存在する ${ }^{21-23)}$ ：この水分子の集合体は主に そのサイズによって inclusion, bubble, clusterなどと呼 ばれている.この種の水分子の集合体は冷却下で涷結す る “水” (freezable) と凍結しない“水” (non-freezable, gel-type)の 2 種の“水”が識別されている(例えば，11）。

変形に寄与する “水”は, 合成石英や紫水晶による実験 から凍結しない水分子の集合体と考えられているが, 最 近では，凍結する水分子の集合体の役割が自然の鉱物の 変形と関連して重要と考えられている2425)。いずれにし ても拡散能は高くはないと考えられているが，包有物の 濃度, サイズと分布(分散の程度)よっては重要であり， かつHydrolytic weakening に対する “水”の供給源とし て有効と考えられている.

\section{3. 石英の変形}

変成岩やマイロナイト中の石英はいろいろな変形構造 ・組織を示す．地殼条件下での石英を主体とする岩石や 石英をかなり含む岩石中の石英の変形はおもに転位機構 によっていると考えられる．また石英にみられる变形構 造・組織の多様性は主に転位構造によっている，石英の
変形実験は，“水”の存在が強度を急激に弱くすること， 即ち, “水”が転位の運動を容易にすることを示した. そして変形を促進し転位密度を上昇させる一方で回復 · 再結晶》を促進することなどを明らかにした．塑性変形 は，低温では主に転位すべりによる变形が，高温になる と転位の上昇(下降)運動を伴って変形が進む．転位すべ りはキンク対形成速度が重要であり，キンク対形成促進 に1のタイプの “水”が大きな役割を演ずるモデル19920) が提案されている，また，回復・再結晶の過程では転位 の上昇(下降)運動をともなう。転位の上昇(下降)運動は ショグの形成・移動速度が重要であり,この場合原子空 孔あるいは原子の拡散を伴う。“水”が上昇(下降)運動 の機構にどの様に関係しているか解っていないが, 酸素 や珪素(実験的な証拠はないが)の拡散を促進する役割を 演じていると考えられている．さらに高温になれば体積 拡散を主体とする変形が進むと考えられるが, 地殼条件 下での石英の変形を考える場合には, 粒界や転位芯での 高速拡散がより重要であろう。また, 粒界の水は溶解一 沈澱機構による変形や再結晶粒の粒界移動, 即ち粒成長 に直接関与する点で重要である.

\section{4. 自然の岩石中の石英の “水”}

中央構造線 (MTL) 沿いの領家花崗岩類は, MTL の 活動によってMTLに近つくほど顕著な变形組織を示 す.この変形組織の形成はおもに転位の運動によってい ると考えられる．そこで, 花崗岩類中の石英の変形の程 度と水の存在量を䫒微赤外分光法によって検討した。 MTL 直上付近から約 $5 \mathrm{~km}$ の範囲までの花崗岩とマイ ロナイト中の石英で, 両面研磨した岩石薄片を使用し, 光学顕微鏡による組織の観察を行いなからら, 目的の部分 (100 $\mu \mathrm{m}$ 径の領域)の顕微 FTIR による石英中の “水” の存在量の測定を行った。結果はFig. 1 に示すように, 石英中の水の量 (岩石薄片中の複数の石英粒中の約 10 地 点での測定値の平均) はMTLに近づくにつれて明かに 増加している. 見積られた“水”の量は, $2500 \mathrm{ppmH} /$ $10^{6} \mathrm{Si}(0.01 \mathrm{wt} \%=655 \mathrm{ppm})$ か $510500 \mathrm{ppm}$ で， Kronenberg and Wolf (1990)25)によるMoine thrust (from 4200 to $7400 \mathrm{ppm}$ ) や Coyote Mounain shear zone

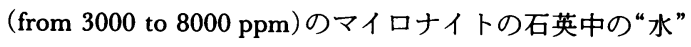
の測定量とほほ同様である. また, 同じ出合ルートで MTL 直上付近から $5 \mathrm{~km}$ までの花崗岩及びマイロナイ ト中の石英の結晶内昰は Fig. 2 に示すように水の量と 同様 MTLに近付くにつれて急速に大きくなる26). 即ち, MTLに近付くにつれて転位密度（最大で約 $5 \times 10^{8} \mathrm{~cm}^{-2}$ ： マイロナイト中の石英での平均値) が増大することを示 


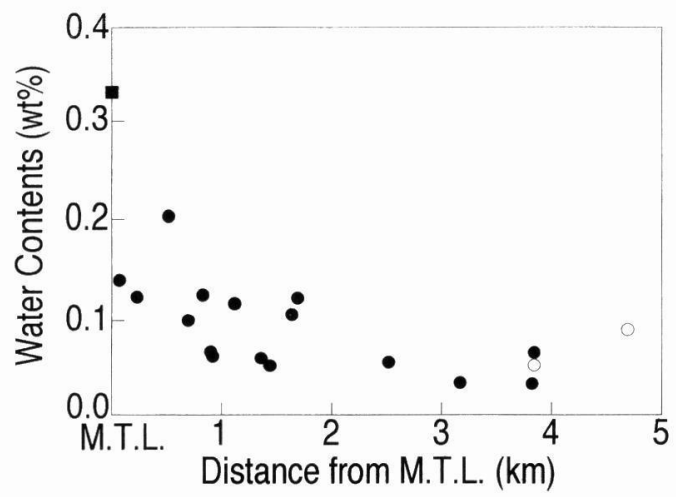

Fig. 1 Water content within naturally deformed quartz as a function of distance from MTL. : Quartz grains within younger granite and its mylonite. $\bigcirc$ : Quartz grain within gneissose granite. (Shinoda et al., in preparation)

している．転位密度の増加と水の量の増加に見られる正 の相関は, 変形と“水” 間になんらかの関連が存在する 可能性を想像させる.

この地域の試料中の石英の IR スペクトルに認められ た $3400 \mathrm{~cm}^{-1}$ 付近のブロードな吸収帯は, Fig. 3 に示す ように冷却下では $3200 \mathrm{~cm}^{-1}$ 付近に中心を示すブロード な吸収帯に変化する。これは水が冷却下で涷結し, 氷に 変化することに対応している6). 即ち, 今回測定された “水”はほとんどが凍結する水で流体包有物中にあると 考えられる。しかし，冷却下での吸収帯の高波数側 (3400 $\mathrm{cm}^{-1}$ 以上) に見られる吸収は凍結しない“水”の 存在を示しているかも知れない. そこで, Fig. 4 に示す ように，花崗岩および花崗岩質マイロナイト中の石英粒 にみられる流体包有物の分布, 包有物のサイズと包有物 密度の違いを検討した.ここで, 石英中の水の存在量と 完全に水で充填された流体包有物の関係を見ると, 0.1 $\mathrm{wt} \%$ の水が一定サイズの球状流体包有物として均一に 分布すると仮定した場合，100 nm 径の包有物であれば 密度は $5 \times 10^{18} \mathrm{~m}^{-3}, 1 \mu \mathrm{m}$ 径で $5 \times 10^{15} \mathrm{~m}^{-3}, 5 \mu \mathrm{m}$ 径で $4 \times 10^{12} \mathrm{~m}^{-3}$ に達する. Fig. $4 \mathrm{~A}, \mathrm{~B}$ は MTL から $1 \mathrm{~km}$ 以 上離れた地点での試料で一般的に認められる流体包有物 の分布と包有物密度を示している. 即ち, MTLから 1 $\mathrm{km}$ 以上の地域での石英中の“水” は, ほとんどの包有 物が線上あるいは面上に配列する微小割れ目を充填した と考えられる水が閉じこめられて形成されたもので, サ イズも大きいもので $5 \mu \mathrm{m}$ 程度に達し, 包有物密度もあ り, 赤外分光法から見積られる水の存在量のほとんどを 流体包有物中の水として説明できそうである.しかし，

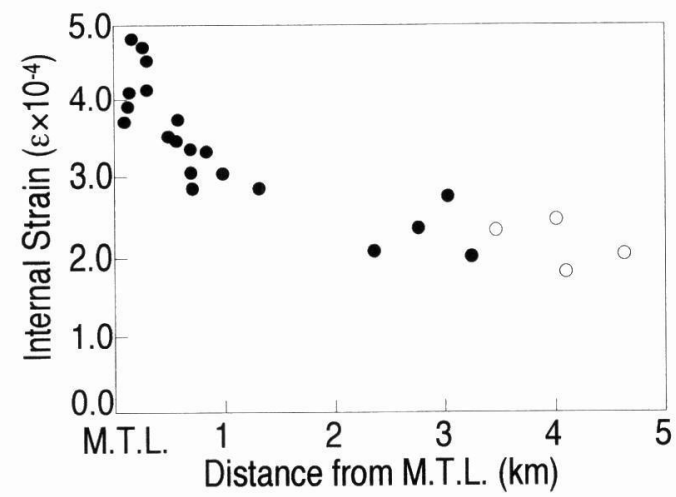

Fig. 2 Apparent internal strain in quartz as a function of distance from MTL. O, $\bigcirc$ : The same as Fig. 1. (Aikawa and Aoyama, 1983)

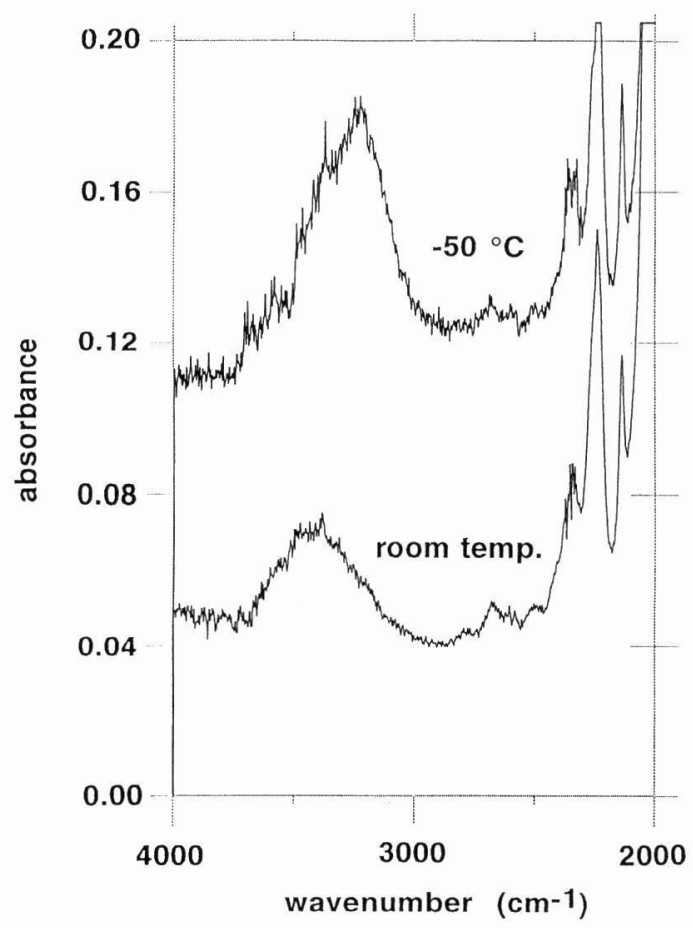

Fig. 3 Typical IR absorption spectrum of naturally deformed quartz in mylonite.

石英粒中の流体包有物のサイズは MTL に近づくと小さ くなるとともに包有物密度はきわめて不均一になり単結 晶粒ごとに大きく変化する. Fig. $4 \mathrm{C}, \mathrm{D}$ は MTLより 1 $\mathrm{km}$ 以内のマイロナイトの石英中に見られる包有物のサ イズと分布を示したもので，包有物のサイズも $1 \mu \mathrm{m}$ 前 後以下と小さく, 包有物密度も際立って高くなく, 光学 

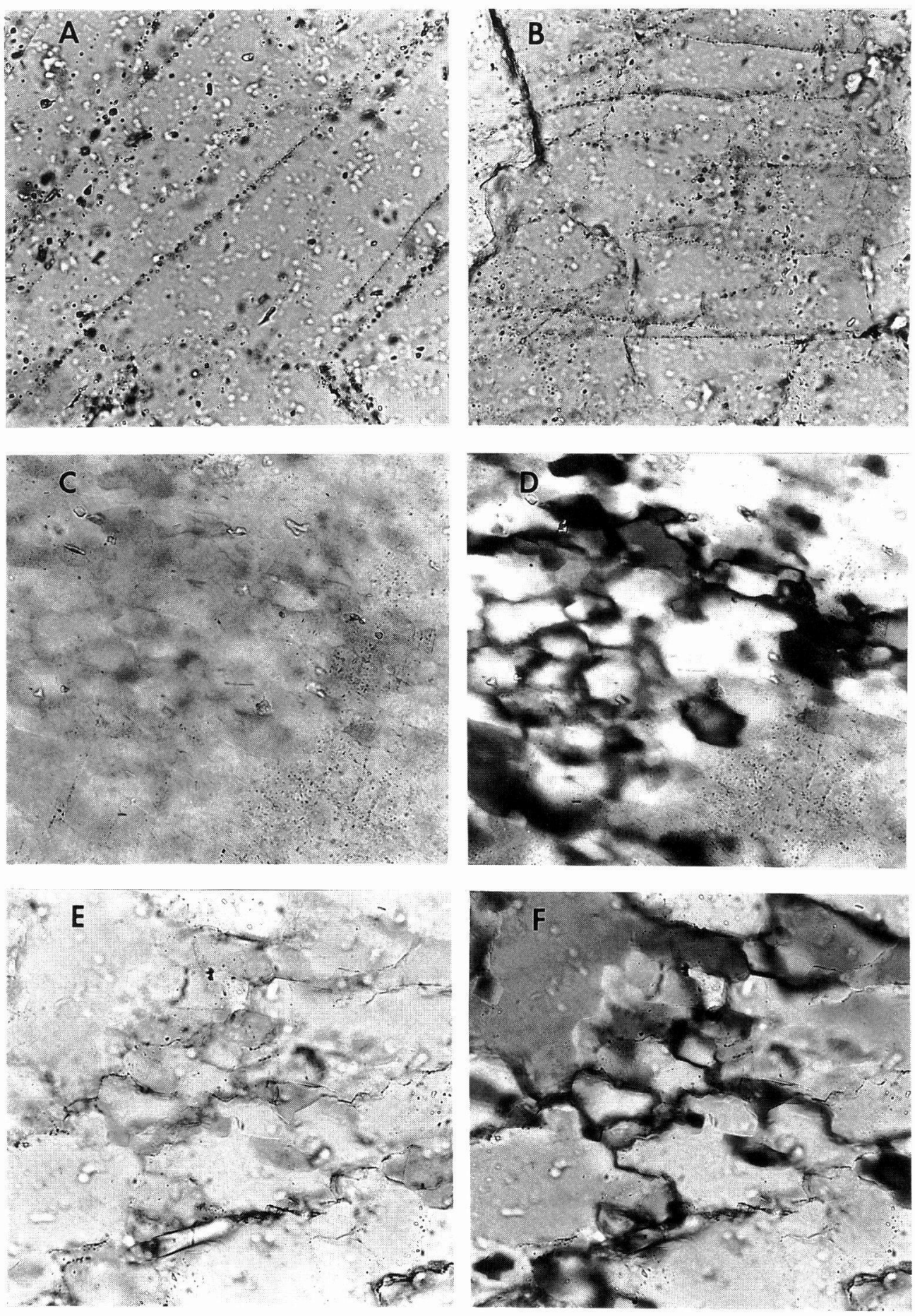

Fig. 4 Details of the microstructure of deformed quartz grains. A and B: Linear and planer arrays of fluid inclusions formed along healed microfracture, in crossed polared. C and D: Recrystallization microstructures in naturally deformed quartz, showing replacement of fluid inclusion-rich old grains by almost inclusion free new ones, in plain polirised light (C) and cross polared (D). E and F: Fluid inclusions have been driven out of the recrystallized grains during recrystallization into the recrystallized grain walls, in plain polarized light (E) and crossed polared (F). Long edge of each photo is $0.2 \mathrm{~mm}$. 
顕微鏡で認められる流体包有物 (約500 $\mathrm{nm}$ 径まで可能) 中の水だけでは赤外分光法で測定された水の存在量を説 明しきれない。このことは光学顕微鏡で確認できない程 度のきわめて小さいサイズ(500 $\mathrm{nm}$ 以下)の流体包有物 が存在しているものと考えられる. 観測された水の量の 一部がこの種の水とすると, その包有物密度はかなり高 く, かつ転位密度も高いことから，包有物が転位と交差 している可能性も高いであろう。また，Fig. 4E，F は再 結晶粒界(動的再結晶?アニーリングの過程?)に見られ る流体包有物(球形で粒界に配列した場合とパイプ状の 粒界に存在する場合がある)で再結晶の過程で粒界に吐 き出され，粒界移動にも寄与したかも知れない。

MTLより $1 \mathrm{~km}$ 以内の石英粒中の水の一部は光学顕 微鏡で識別できないほど細粒の流体包有物中に存在する 可能性を指摘したが, Ord and Christie (1983) 27)は, Moine thrust のマイロナイト中の石英の電子顕徽鏡観察 で，転位と交差する100-200 nm の bubble(彼らは voids と記載）を見いたしている．同種の bubble は合成石英 のアニーリングに伴って形成 ${ }^{21)-23)}$ され，そのサイズや 形成頻度は圧力依存性(高圧下ではサイズが小さかった り, 生成されない)を示し一般的に転位と交差してい $ろ^{28) 29)}$. Kronenberg and wolf (1990) ${ }^{25)}$ は同じMoine thrust の石英の冷却下での赤外吸収スペクトルから涷結 しない“水”の存在を明らかにした．この種の凍結しな い“水”は, bubbleに対応しているかもしれないし少 量でも包有物密度が高く, パイプ拡散によって転位の運 動に，また“水”の供給源として hydrolytic weakening に直接寄与すると考えられ, 地殼内で広く認められる Hydrolytic weakening 現象と関連して重要と考えられて いる24)25). MTLより $1 \mathrm{~km}$ 以内のマイロナイト中の石 英にも同種の “水”が存在する可能性が高いが, 今後電 子顕徽鏡と冷却下での赤外吸収スペクトルによる確認が 必要と考えている.

\section{5. おわりに}

自然の岩石中の石英に含まれる“水”はサイズの大小 はあるが流体包有物中に存在している水で, 一部に凍結 しない“水”の存在の可能性が高いが, 合成石英や柴水 晶に見いだされる “水”とは異なる. 一方, 流体包有物 は転位の生成·増殖に重要であることが指摘されると同 時に回復·再結晶(転位の移動・上昇・消隇過程を含む) を促進することが指摘されている. しかし, 石英の強度 に急激な低下をむたらす “水”が凍結しない“水”とす ると, マイロナイト以外の自然の岩石中の石英にも凍結 しない“水”が普遍的に見いたされるのであろうか？あ るいは“wet”な合成石英の変形メカニズムと自然での 石英の変形メカニズムは違うのであろうか? ?マイロナイ トに見いだされた細粒の bubble は，もともと合成石英 や紫水晶にみられると同様な“水”として溶け込んでい たものが, 温度 ·圧力の低下にともなって石英構造中か ら離溶し，形成されたのであろうか？その意味で，石英 中への温度 ·圧力下での “水” の溶解度, “水” の払散 速度の決定など実験的研究, あるいは天然の各種岩石中 の石英にみられる“水” の化学種 · 存在量や分布に関す る研究は重要と考えられる.

謝辞 : 研究発表の機会を与えていたたいた鉱物学会年会 シンポジウム実行委員会の方々に感謝します，また石英 中の水の分析結果を提供下さった大阪市大理学部篠田圭 司氏，吉田貴美子さんに感謝します。なおこの研究費の 一部は文部省の科学研究費補助金を使用して行なった。

\section{文献}

1) Griggs, D. T. and Blacic, J. D. (1965): Quartz: Anomalous weakeness of syntheticcrystals. Science, 147, 292-295.

2) Griggs, D. T. (1967): Hydrolytic weakening of quartz and other silicates. Geophys, J. R. astr. Soc., 14, 19-31.

3) Gilleti, B. J. and Yund, R. A. (1984): Oxygen diffusion in quartz. J. G. R., 89, 4039-4046.

4) Dennis, P. F. (1984): Oxygen self-diffusion in quartz under hydrothermal conditions. J. G. R., 89, 4047-4058.

5) Elphick, S. C. and Graham, C. M. (1988): The effect of hydrogen on oxygen diffuion in quartz: edidence for fast proton transients? Nature, 335, 243-245.

6) Aines, R. D. and Rossman, G. R. (1984): Water in minerals? Apeak in the infrared. J. G. R., 89, 4059-4071.

7) Hobbs, B. E. (1968): Recrystallization of single crystals of quartz. Tectonophysics, 6, 353-401.

8) Donnay, G., Wyart, J., and Sabatier, G. (1959): Structural mechanism of thermal and compositional transformations in silicates. Zeit. Kristallogr., 112, 161-168.

9) Dowty, E. (1980): Crystal-chemical factors affecting the mobility if ions in minerals. Amer. Mineral., 65, 174-182.

10) Kats, A. (1962): Hydrogen in alpha-quartz. Philips Res. Reports, 17, 1-33, 133-279.

11) Kekulawala, K. R. S. S., Paterson, M. S. and Boland, J. N. (1978): Hydrolytic weakeningin quartz. Tectonophysics, 46, T1-T6.

12) Aines, R. D., Kirby, S. H. and Rossman, G. R. (1984): Hydrogen speciation in synthetic quartz. Phys. Chem. Minerals, 11, 204-212.

13) Cordier, P. and Doukhan, J. C. (1991): Water speciation in quartz: A near infrared study. Amer. Mineral., 76, 361-369.

14) Paterson, M. S. (1989): The interaction of water with quartz and its influence indislocation flow - an overview. 
in Rheology of Solidsand of the Earth, ed. by Karato, S. and Toriumi, M., Oxford University Press, 107-142.

15) Aines, R. D. and Rossman, G. R. (1984): The hydrous component in garnets:pyralsites. Amer. Mineral., 69, $1116-1126$

16) Weil, J. A. (1984): A rewiew of electron spin spectroscopy and its application to the study of paramagnetic defects in crystalline quartz. Phys.Chem.Minerals, 10, 149-165.

17) Paterson, M. S. (1986): The thermodynamics of water in quartz. Phys. Chem. Minerals, 13, 245-255.

18) Hagon, J. P., Stoneham, A. M., and Jaros, M. (1987): Transport processes in silicon oxidation, I Dry oxidation, II Wet oxidation. Phil. Mag. B, 55, 221-224, 225-235.

19) Griggs, D. T. (1974): A model of hydrolytic weakening in quartz. J. G. R., 79, 1653-1661.

20) Doukhan, J. C. and Trepied, L. (1985): Plastic deformation of quartz single crystal. Bulletin de Minerealogie, 108, 97-123.

21) McLaren, A. C., and Phakey, P. P. (1966): Transmission electron microscope study of bubbles and dislocations in amethyst and citrine quartz. Australian J. Physics, 19, 1924.

22) Morrison-Smith, D. J., Paterson, M. S., and Hobbs, B. E. (1976): An electron microscope study of plastic deformation in single crystals of synthetic quartz. Tectonophysics, 33, 43-79.
23) McLaren, A. C., Cook, R. F., Hyde, S. T., and Tobin, R. C. (1983): The mechanisms of the formation and growth of water bubbles and associated dislocation loops in synthetic quartz. Phys. Chem. Minerals, 9, 79-94.

24) Gerretsen, J., Paterson, M. S., and McLaren, A. C. (1989): The uptake and solubility of water in quartz at elevated pressure and temperature. Phys. Chem. Minerals, 16, 334-342.

25) Kronenberg, A. K. and Wolf, G. (1990): Fourier transform infrared spectroscopy determinations of intergranular water content in quartz-bearing rocks: implications for hydrolytic weakening in the laboratory and within the earth. Tectonophysics, 172, 255-271.

26）相川信之, 青山俊宏 (1983)：中央構造線に近接する花 崗岩類の变形.鉱物学雑誌, 16 巻, 特別号 1 号, 251255.

27) Ord, A. and Christie, J. M. (1984): Flow stresses from microstructures in mylonitic quartzites of the Moine Thrust zone, Assynt area, Scotland. Joul. Struct. Geol., 6, 639-654.

28) Jones, M. E. (1978): The influence of hydrostatic pressure on the precipitation of structure-bound water in micro-inclusions in quartz. Phil. Mag., 37, 703-706.

29) Cordier, P. and Doukhan, J. C. (1989): Water solubility in quartz and its influence on ductility. Eur. J. Mineral., 1, 221-237. 